\title{
Sampling a Littoral Fish Assemblage: Comparison of Small-Mesh Fyke Netting and Boat Electrofishing
}

\author{
Carl R. Ruetz III* and Donald G. Uzarski \\ Annis Water Resources Institute, Grand Valley State University, 740 West Shoreline Drive, \\ Muskegon, Michigan 49441, USA \\ DAMON M. KRUEGER \\ School of Natural Resources and Environment, University of Michigan, Dana Building, \\ 430 East University Avenue, Ann Arbor, Michigan 48109, USA \\ EDWARD S. RUTHERFORD \\ Institute for Fisheries Research, University of Michigan, 212 Museums Annex Building, \\ Ann Arbor, Michigan 48109, USA
}

\begin{abstract}
We compared small-mesh (4-mm) fyke netting and boat electrofishing for sampling a littoral fish assemblage in Muskegon Lake, Michigan. We hypothesized that fyke netting selects for small-bodied fishes and electrofishing selects for large-bodied fishes. Three sites were sampled during May (2004 and 2005), July (2005 only), and September (2004 and 2005). We found that the species composition of captured fish differed considerably between fyke netting and electrofishing based on nonmetric multidimensional scaling (NMDS). Species strongly associated with fyke netting (based on NMDS and relative abundance) included the brook silverside Labidesthes sicculus, banded killifish Fundulus diaphanus, round goby Neogobius melanostomus, mimic shiner Notropis volucellus, and bluntnose minnow Pimephales notatus, whereas species associated with electrofishing included the Chinook salmon Oncorhynchus tshawytscha, catostomids (Moxostoma spp. and Catostomus spp.), freshwater drum Aplodinotus grunniens, walleye Sander vitreus, gizzard shad Dorosoma cepedianum, and common carp Cyprinus carpio. The total length of fish captured by electrofishing was $12.8 \mathrm{~cm}(95 \%$ confidence interval $=5.5-$ $17.2 \mathrm{~cm}$ ) greater than that of fish captured by fyke netting. Size selectivity of the gears contributed to differences in species composition of the fish captured, supporting our initial hypothesis. Thus, small-mesh fyke nets and boat electrofishers provided complementary information on a littoral fish assemblage. Our results support use of multiple gear types in monitoring and research surveys of fish assemblages.
\end{abstract}

Sampling littoral fish assemblages is an important component of ecological assessment in many lakes. Choosing the most appropriate gear for fish sampling can be difficult due to the many options available (Murphy and Willis 1996). To further complicate matters, a single sampling gear usually provides only a

\footnotetext{
* Corresponding author: ruetzc@gvsu.edu
}

Received May 21, 2006; accepted October 23, 2006 Published online July 16, 2007 partial representation of a fish assemblage because it cannot capture all species and size-classes (Murphy and Willis 1996). Consequently, use of multiple sampling gears instead of a single gear often provides a better representation of fish species composition and size structure in lakes and wetlands (Weaver et al. 1993; Knight and Bain 1996; Fago 1998; Shoup et al. 2003; Lapointe et al. 2006; but see Pugh and Schramm [1998] and Vaux et al. [2000]). Nevertheless, careful evaluation of multiple gears is needed before initiating fish sampling to ensure that the information gained by each gear is sufficiently different to justify the additional effort of using multiple gears.

Our goal was to compare two common gears-fyke nets and electrofishers-for sampling littoral fish assemblages. Although previous studies have compared these gear types (e.g., Knight and Bain 1996; Fago 1998; Pugh and Schramm 1998; Vaux et al. 2000; Lapointe et al. 2006), few evaluations have focused on species composition and size structure of fish collected with small-mesh fyke nets and boat electrofishers in littoral habitats of lakes. Our objective was to determine whether small-mesh fyke nets and boat electrofishers provided complementary or redundant information on littoral species composition and size structure. We hypothesized that small-mesh fyke nets would select small-bodied fishes (Brazner et al. 1998; Breen and Ruetz 2006), whereas electrofishing would select large-bodied species (Chick et al. 1999; Dolan and Miranda 2003). Moreover, movement patterns should affect the catchability of fishes in passive and active gears; therefore, fyke netting should select mobile fishes (Hubert 1996) and electrofishing should select sedentary fishes (Reynolds 1996).

\section{Methods}

Study site.-Muskegon Lake (1,697-ha surface area; Muskegon County, Michigan) is located on the eastern 
shore of Lake Michigan. The lake was formed by the combination of sand dunes constricting the flow of the Muskegon River (MR) before it enters Lake Michigan and inundation of the ancient river valley formed when historic Great Lakes levels were much lower (Jude et al. 2005). Fish were sampled at three fixed littoral-zone sites representing a gradient from the mouth of MR to Lake Michigan in areas with relatively natural shoreline (much of the lake has hardened shoreline). Sites were located at the mouth of the MR's north channel $\left(43^{\circ} 15.39^{\prime} \mathrm{N}, 86^{\circ} 15.29^{\prime} \mathrm{W}\right)$, mid-lake along the north shoreline near Johnson's Point (JP; $43^{\circ} 14.59^{\prime} \mathrm{N}$, $86^{\circ} 16.91^{\prime} \mathrm{W}$ ), and near the sand dunes at Muskegon State Park (SP; $\left.43^{\circ} 14.55^{\prime} \mathrm{N}, 86^{\circ} 19.57^{\prime} \mathrm{W}\right)$. Substrate was primarily sand at all sites. Water depth measured during fyke netting was $76-85 \mathrm{~cm}$ at $\mathrm{MR}, 56-76 \mathrm{~cm}$ at $\mathrm{JP}$, and $59-73 \mathrm{~cm}$ at $\mathrm{SP}$; specific conductivity was 319-443 $\mu \mathrm{S} / \mathrm{cm}$ at MR, 310-397 $\mu \mathrm{S} / \mathrm{cm}$ at JP, and $307-388 \mu \mathrm{S} / \mathrm{cm}$ at $\mathrm{SP}$. Water temperature measured during fyke netting was $11-15^{\circ} \mathrm{C}$ during spring, 26$31^{\circ} \mathrm{C}$ during summer, and $20-27^{\circ} \mathrm{C}$ during fall. The SP site typically lacked submerged aquatic vegetation, but such vegetation usually became established at JP and MR during mid- to late summer.

Sampling design and protocol.-Fykenetting and boat electrofishing were conducted at each study site. Boat electrofishing was usually conducted within $9 \mathrm{~d}$ of fykenetting (range $=0-20 \mathrm{~d}$ ). Each study site was sampled during May (2004 and 2005), July (2005 only), and September (2004 and 2005). However, observations (both fyke netting and electrofishing) at MR during May 2005 were not included in our analyses because inclement weather prevented the completion of the electrofishing transect at that site. Thus, our analysis is based on 14 observations of fykenetting and electrofishing catch.

Three fyke nets were set at each site in shallow areas (depth $<1 \mathrm{~m}$ ) during a sampling event. Two nets were positioned parallel to the shoreline (leads fished end to end) and one net was positioned perpendicular to the shoreline (mouth of net facing shoreline) to increase the likelihood of capturing fish swimming along the shoreline (perpendicular set) and those swimming between deeper and shallower areas (parallel set). Distance between perpendicular and parallel fyke nets was about $25-50 \mathrm{~m}$. Fyke nets were set during daylight conditions between 1043 and 1600 hours and retrieved to process fish after about $24 \mathrm{~h}$ (i.e., 1 net-night). Fish were identified to species, measured to the nearest 1 $\mathrm{mm}$ total length (TL), and released.

The design of the fyke nets was similar to that commonly used throughout the Great Lakes basin (e.g., Brazner et al. 1998; Uzarski et al. 2005) and is described in detail by Breen and Ruetz (2006). Fyke nets were constructed of 4-mm mesh; a lead (length $=$ $7.20 \mathrm{~m}$ ) extended from the middle of the net's mouth $(1.2 \times 0.9 \mathrm{~m})$, and the wings (length $=1.75 \mathrm{~m})$ extended from each side of the mouth (at $45^{\circ}$ to the lead).

We used a Smith-Root electrofishing boat (7.5 generator-powered pulsator control box; pulsed DC) to sample littoral fish assemblages at night. The current ranged from 4 to $6 \mathrm{~A}$ at $240 \mathrm{~V}$. Transects were $10 \mathrm{~min}$ (pedal time) in duration and were conducted parallel to shoreline between 2013 and 0040 hours at each site (in areas with relatively homogenous habitat); two people netted fish from the bow while the boat was run at idle speed. Distance of the electrofishing transects was about 500-750 m. Fish were held in a recirculating live well until the completion of each transect, when captured fish were identified, measured, and released.

Data analysis.-We used nonmetric multidimensional scaling (NMDS) to explore differences in community composition between fyke netting and electrofishing (McCune and Grace 2002). The input data for NMDS were relative abundance (i.e., proportion) of each species collected at a site during a sampling event (for each gear), which provided a stronger basis to make comparisons given that sampling effort (fykenetting $=3$ net-nights; electrofishing $=10$-min pedal time) differed between gears. The NMDS was performed with the Bray-Curtis distance measure (Kruskal and Wish 1978), 400 maximum iterations, 40 runs with real data, and 50 randomized runs for Monte Carlo permutation procedure in PC-ORD (version 4.0; MjM Software). We used a three-dimensional solution of NMDS because the change in stress (i.e., measure of optimality of an ordination solution) was minimal with additional dimensions (see McCune and Grace 2002). A blocked multiresponse permutation procedure (MRPP; Zimmerman et al. 1985) was performed in PC-ORD to test for differences in community composition between gears. Each site sampling event was a block. We used Euclidean distance measures, natural weighting, and median alignment within blocks in the MRPP. Finally, differences in the mean TL of captured fish were compared between the two gears with a paired $t$-test, and a $95 \%$ confidence interval (CI) of that difference was calculated as a measure of effect size (sampling events at each site were treated as independent observations).

\section{Results}

Fyke netting captured 2,177 fish representing 34 species, whereas boat electrofishing captured 760 fish representing 33 species. Five species were collected only by fyke netting and four species were collected 
TABLE 1.-Catch statistics and loadings (i.e., species scores) for axis 2 of a nonmetric multidimensional scaling ordination used to evaluate differences in the Muskegon Lake, Michigan, littoral fish community between samples collected by fyke netting and electrofishing 2004-2005. Relative abundance (RA; \% of total catch), number of observations $(O)$ with at least one individual $(O \geq 1$; total $=14$ site sampling observations $)$, and mean TL $( \pm \mathrm{SE})$ are reported. Relative abundance and mean TL were based on data pooled across sites and sampling events.

\begin{tabular}{|c|c|c|c|c|c|c|c|c|}
\hline \multirow[b]{2}{*}{ Species } & \multicolumn{3}{|c|}{ Fyke netting } & \multicolumn{3}{|c|}{ Boat electrofishing } & \multirow[b]{2}{*}{ Comb RA ${ }^{b}$} & \multirow[b]{2}{*}{ Axis 2} \\
\hline & RA & $O \geq 1$ & $\mathrm{TL}^{\mathrm{a}}$ & RA & $O \geq 1$ & $\mathrm{TL}^{\mathrm{a}}$ & & \\
\hline Mimic shiner Notropis volucellus & 22.5 & 3 & $5.3 \pm 0.2$ & 0 & 0 & - & 16.7 & 0.61 \\
\hline Round goby Neogobius melanostomus & 18.1 & 12 & $4.8 \pm 0.1$ & 1.1 & 2 & $7.1 \pm 0.8$ & 13.7 & 0.69 \\
\hline Yellow perch Perca flavescens & 13.9 & 6 & $8.3 \pm 0.1$ & 2.2 & 5 & $11.7 \pm 1.0$ & 10.9 & 0.09 \\
\hline Rock bass Ambloplites rupestris & 8.0 & 14 & $9.6 \pm 0.2$ & 4.9 & 8 & $13.1 \pm 0.5$ & 7.2 & 0.24 \\
\hline Brook silverside Labidesthes sicculus & 8.5 & 8 & $7.4 \pm 0.0$ & 1.2 & 3 & $8.4 \pm 0.2$ & 6.6 & 0.87 \\
\hline Bluntnose minnow Pimephales notatus & 7.5 & 14 & $5.9 \pm 0.1$ & 3.7 & 2 & $8.2 \pm 0.2$ & 6.5 & 0.53 \\
\hline Largemouth bass Micropterus salmoides & 5.9 & 8 & $5.4 \pm 0.1$ & 7.4 & 10 & $20.4 \pm 1.7$ & 6.3 & -0.20 \\
\hline Pumpkinseed Lepomis gibbosus & 2.8 & 9 & $7.2 \pm 0.4$ & 12.1 & 13 & $14.1 \pm 0.2$ & 5.2 & -0.48 \\
\hline Bluegill Lepomis macrochirus & 2.1 & 10 & $6.8 \pm 0.5$ & 11.2 & 13 & $13.3 \pm 0.3$ & 4.5 & -0.36 \\
\hline Spottail shiner Notropis hudsonius & 2.9 & 11 & $8.6 \pm 0.3$ & 7.6 & 8 & $9.8 \pm 0.2$ & 4.1 & 0.09 \\
\hline Gizzard shad Dorosoma cepedianum & 0.9 & 5 & $9.8 \pm 0.6$ & 11.7 & 7 & $17.1 \pm 1.0$ & 3.7 & -0.62 \\
\hline White perch Morone americana & 1.8 & 6 & $6.4 \pm 0.3$ & 8.6 & 10 & $13.1 \pm 0.5$ & 3.5 & -0.33 \\
\hline Trout-perch Percopsis omiscomaycus & 0.3 & 3 & $10.1 \pm 1.1$ & 5.7 & 2 & $8.6 \pm 0.3$ & 1.7 & -0.43 \\
\hline Walleye Sander vitreus & 0.1 & 2 & $23.2 \pm 5.8$ & 5.1 & 9 & $24.4 \pm 2.0$ & 1.4 & -0.63 \\
\hline Banded killifish Fundulus diaphanus & 1.5 & 6 & $6.1 \pm 0.2$ & 0.4 & 3 & $7.1 \pm 0.6$ & 1.2 & 0.72 \\
\hline Golden redhorse Moxostoma erythrurum & $<0.1$ & 1 & 19.5 & 3.8 & 7 & $31.8 \pm 2.0$ & 1.0 & -0.68 \\
\hline Bowfin Amia calva & 0.4 & 6 & $63.7 \pm 1.2$ & 2.4 & 7 & $58.2 \pm 1.6$ & 0.9 & -0.36 \\
\hline White sucker Catostomus commersonii & 0.3 & 4 & $21.7 \pm 8.1$ & 2.4 & 7 & $35.1 \pm 2.0$ & 0.8 & -0.52 \\
\hline Smallmouth bass Micropterus dolomieu & 0.8 & 2 & $5.6 \pm 0.3$ & 0.3 & 2 & $42.2 \pm 11.2$ & 0.7 & 0.06 \\
\hline Silver redhorse Moxostoma anisurum & 0.2 & 4 & $56.1 \pm 4.7$ & 1.4 & 5 & $42.1 \pm 3.7$ & 0.5 & -0.72 \\
\hline Alewife Alosa pseudoharengus & 0.2 & 3 & $12.7 \pm 2.4$ & 1.1 & 3 & $15.3 \pm 1.0$ & 0.4 & -0.03 \\
\hline Shorthead redhorse Moxostoma macrolepidotum & 0.1 & 1 & $19.6 \pm 8.7$ & 0.8 & 5 & $32.9 \pm 5.1$ & 0.3 & -0.44 \\
\hline Chinook salmon Oncorhynchus tshawytscha & 0 & 0 & - & 0.9 & 3 & $87.6 \pm 2.2$ & 0.2 & -0.94 \\
\hline Common carp Cyprinus carpio & $<0.1$ & 1 & 9.5 & 0.8 & 5 & $70.9 \pm 2.4$ & 0.2 & -0.51 \\
\hline Rainbow trout Oncorhynchus mykiss & 0 & 0 & - & 0.8 & 4 & $30.6 \pm 7.2$ & 0.2 & -0.36 \\
\hline Freshwater drum Aplodinotus grunniens & $<0.1$ & 1 & 31.0 & 0.7 & 5 & $37.7 \pm 4.6$ & 0.2 & -0.70 \\
\hline Logperch Percina caprodes & 0.2 & 2 & $7.8 \pm 0.6$ & 0.1 & 1 & 9.8 & 0.2 & -0.35 \\
\hline Channel catfish Ictalurus punctatus & 0.1 & 1 & $68.8 \pm 1.8$ & 0.4 & 1 & $51.9 \pm 3.5$ & 0.2 & -0.56 \\
\hline Longnose gar Lepisosteus osseus & $<0.1$ & 1 & 39.5 & 0.4 & 3 & $66.1 \pm 16.5$ & 0.1 & -0.75 \\
\hline Common shiner Luxilus cornutus & 0.2 & 2 & $7.8 \pm 2.0$ & 0 & 0 & - & 0.1 & 1.02 \\
\hline Quillback Carpiodes cyprinus & 0 & 0 & - & 0.4 & 2 & $41.2 \pm 6.8$ & 0.1 & -0.75 \\
\hline Emerald shiner Notropis atherinoides & $<0.1$ & 1 & 10.3 & 0.3 & 1 & $9.5 \pm 1.5$ & 0.1 & -0.52 \\
\hline Black crappie Pomoxis nigromaculatus & 0.1 & 2 & $7.2 \pm 2.0$ & 0.1 & 1 & 23.1 & 0.1 & -0.48 \\
\hline Tadpole madtom Noturus gyrinus & 0.1 & 3 & $4.9 \pm 1.3$ & 0 & 0 & - & 0.1 & 0.47 \\
\hline Northern pike Esox lucius & $<0.1$ & 1 & 22.1 & 0.1 & 1 & 64.1 & 0.1 & -0.39 \\
\hline Black bullhead Ameiurus melas & 0 & 0 & - & 0.1 & 1 & 10.9 & $<0.1$ & 0.03 \\
\hline Brown bullhead Ameiurus nebulosus & $<0.1$ & 1 & 6.5 & 0 & 0 & - & $<0.1$ & 1.06 \\
\hline Yellow bullhead Ameiurus natalis & $<0.1$ & 1 & 32.8 & 0 & 0 & - & $<0.1$ & 0.64 \\
\hline
\end{tabular}

${ }^{a} \mathrm{SE}$ is not reported for TL when $N=1$.

${ }^{\mathrm{b}}$ Combined catch (i.e., fyke netting plus electrofishing).

only by electrofishing (Table 1). A total of 38 species was captured by both gears, but less than half (i.e., 16 species) accounted for more than $1 \%$ of the combined catch (Table 1). Most common species were captured at multiple sites and sampling events (Table 1); however, more than $99 \%$ of mimic shiners were collected by fyke netting at SP during summer 2005.

The captured fish species composition differed between fyke netting and electrofishing. The second dimension of the NMDS ordination explained the greatest amount of variation (i.e., 35\%) in species composition of any single dimension and was the best discriminator of gear type (Figure 1). The first and third dimensions explained $20 \%$ and $24 \%$ of the variation, respectively, and represented a combination of season and year effects (not shown). The Monte Carlo test indicated that our three-dimensional real-data solution reduced stress significantly more than could be expected by chance alone $(P<0.020)$. Stress for the three-dimensional solution stabilized at 13.5 after 35 iterations. More importantly, the MRPP indicated that the difference in species composition between fyke netting and electrofishing was significant $(P<0.001)$. Analyzing data stratified by year did not change our general conclusions.

Both common and rare species were associated with the separation of gears in the NMDS ordination. Fish associated with fyke netting had positive species scores on axis 2, whereas fish associated with electrofishing had negative species scores on axis 2 (Figure 1). 


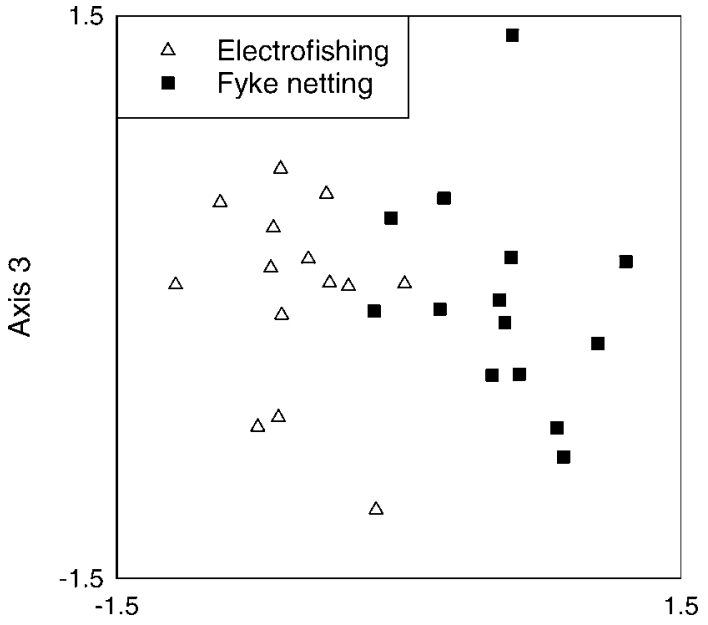

Axis 2

FIGURE 1.-Nonmetric multidimensional scaling ordination of littoral fish assemblages at Muskegon Lake, Michigan, sites sampled with fyke netting and boat electrofishing in 2004 and 2005. Axis 2 was the best discriminator of gear type.

Species strongly associated with fyke netting were the brown bullhead, common shiner, brook silverside, banded killifish, round goby, yellow bullhead, mimic shiner, bluntnose minnow, and tadpole madtom (Table 1). Species strongly associated with electrofishing were the Chinook salmon, longnose gar, quillback, silver redhorse, freshwater drum, golden redhorse, walleye, gizzard shad, channel catfish, white sucker, emerald shiner, and common carp (Table 1). Limiting the NMDS ordination to species representing more than $1 \%$ of combined catch or more than $1 \%$ of catch within each gear did not change the conclusion that species composition differed between gears.

Fish (mean TL $=7.6 \mathrm{~cm}, \mathrm{SE}=0.5 \mathrm{~cm}$ ) collected by fyke netting were significantly smaller than those (mean $\mathrm{TL}=20.4 \mathrm{~cm}, \mathrm{SE}=1.9 \mathrm{~cm}$ ) collected by electrofishing $(t=6.33$, df $=13, P<0.001)$. On average, fish captured by electrofishing were $12.8 \mathrm{~cm}$ $(95 \% \mathrm{CI}=5.5-17.2 \mathrm{~cm})$ larger than those captured by fykenetting. This trend was apparent for 25 of 29 species captured by both gears (Table 1).

\section{Discussion}

Species composition and size structure of fish sampled by fyke netting differed from those of fish sampled by boat electrofishing in Muskegon Lake. Fyke netting targeted smaller fish than electrofishing, which partially explains the difference in species composition between gears. Seven of 9 fishes (i.e., common shiner, brook silverside, banded killifish, round goby, mimic shiner, bluntnose minnow, and tadpole madtom) most strongly associated with fyke netting (based on species' scores from NMDS ordination) are typically small bodied as adults, whereas 11 of 12 species most strongly associated with electrofishing are large bodied as adults (see Becker [1983] and Hubbs et al. [2004] for lengths of fishes). Some of the small-bodied fishes associated with fyke netting exhibit schooling behavior (e.g., common shiner, brook silverside, banded killifish, mimic shiner, and bluntnose minnow) and are considered mobile (Becker 1983); these traits make them more susceptible to passive gears (Hubert 1996). Catostomids accounted for 4 of 12 species most strongly associated with electrofishing and are often considered sedentary during the nonbreeding season (Becker 1983; Bunt and Cooke 2001); thus, they are more susceptible to active gears (Reynolds 1996). However, some mobile species (e.g., Chinook salmon and gizzard shad) were primarily captured by electrofishing, which may have been caused by both avoidance of fyke netting and increased susceptibility to electrofishing. Finally, our results were consistent with findings in Great Lakes coastal wetlands, where the catch of small-mesh fyke nets was dominated by young-of-the-year fish and small-bodied adults (Brazner et al. 1998; Uzarski et al. 2005).

Size selectivity of electrofishing and fyke netting contributed to differences in species composition of the catch. Our findings in Muskegon Lake support (1) laboratory work indicating that electrofishing is highly size selective and unlikely to represent a fish assemblage of both small- and large-bodied species (Dolan and Miranda 2003) and (2) field studies in wetlands, where electrofishing was biased toward larger individuals (Chick et al. 1999). The selectivity of fyke netting for small-bodied species was probably a consequence of the design of our fyke nets, which were constructed with small mesh $(4 \mathrm{~mm})$ and had moderate throat size (diameter $=15 \mathrm{~cm})$. Entrapment gear with larger mesh and throat sizes would probably target larger fish (Holland and Peters 1992; Shoup et al. 2003). Physical constraint (based on throat size) should not have prohibited entry of fish larger than we typically captured in fyke nets; therefore, the lack of larger fish in our nets indicates that these fish are more likely to avoid entrapment gear when mesh size is small relative to their body size. However, fish approaching the physical constraint limits of entrapment gear are often not well represented in the catch (Shoup et al. 2003).

Given the widespread use of entrapment gear (i.e., fyke, trap, and hoop nets) and boat electrofishers for sampling fish (Hubert 1996; Reynolds 1996), relatively few studies have evaluated the benefits of using the 
two gears in combination. Unfortunately, some of those studies used gears with unique designs that prevent comparisons with our study. For instance, trap nets used by Knight and Bain (1996) consisted of minnow traps sewn into a seine, and mini fyke nets used by Fago (1998) had 2.5-cm-mesh exclusion netting over the mouth of the net, which limited entry of large fish. Studies conducted in large rivers found that boat electrofishing both captured more fish species than hoop netting (Pugh and Schramm 1998) and did not differ markedly from hoop netting (Lapointe et al. 2006). We found that small-mesh fyke nets and boat electrofishers captured similar numbers of species, even though the relative abundance of species differed between gears. Lapointe et al. (2006) suggested that the main reason their findings differed from the findings of Pugh and Schramm (1998) was that they electrofished a microhabitat (i.e., held boat over center of a site) rather than using a transect approach. Mesh size (25-35 $\mathrm{mm}$ ) of hoop nets used by Pugh and Schramm (1998) also was considerably larger than that used by Lapointe et al. (2006). In contrast to our findings, Lapointe et al. (2006) did not find strong differences in species composition between small-mesh hoop nets and boat electrofishers, although they analyzed species composition based on presence-absence rather than relative abundance. Finally, a study of the littoral habitat of lakes reported that electrofishing (conducted from a boat with backpack or barge electrofishing units) captured more species than trap netting and thus provided an effective alternative (Vaux et al. 2000), as the two gears provided redundant information. Integrating our findings with those of previous studies suggests that gear bias is habitat specific and is strongly dependent on gear design and sampling protocols.

Although electrofishing is generally expected to select larger fishes (e.g., Chick et al. 1999), comparisons of captured fish size structure between entrapment gear and boat electrofishing have reported mixed results. Entrapment gear captured smaller northern pikeminnow Ptychocheilus oregonensis (Beamesderfer and Rieman 1988) and crappies Pomoxis spp. (Sammons et al. 2002) and larger smallmouth bass (Beamesderfer and Rieman 1988; Milewski and Willis 1991) and bluegills (Schultz and Haines 2005) than did electrofishing. Negligible differences in size were reported for walleyes (Beamesderfer and Rieman 1988) and American eels Anguilla rostrata (Reynolds and Holliman 2004) captured with the two gear types. Electrofishing also was reported to typically sample a wider range of sizes than hoop netting, but clear, consistent differences in fish size structure between the two gear types were not apparent (Pugh and Schramm 1998). The larger mesh size (range $=13-50 \mathrm{~mm}$ ) of entrapment gear used in the aforementioned studies is the most likely explanation of why size selectivity in entrapment gears varied among past studies and often differed with our findings.

Identifying appropriate sampling gears for detecting and monitoring invasive fishes is a high priority for fisheries managers (e.g., Basler and Schramm 2006; Diana et al. 2006). The round goby is an invader in North America and Europe (Corkum et al. 2004), and monitoring of their spread and population trends is therefore of considerable interest (Clapp et al. 2001; Sapota 2004; Johnson et al. 2005). We found that small-mesh fyke nets readily captured round gobies in shallow-water habitats and were much more efficient at collecting round gobies than boat electrofishing at night. Previous work in Muskegon Lake also suggested that small-mesh fyke nets were a better option for sampling round gobies than daytime beach seining (Breen and Ruetz 2006). Although our results and those of Breen and Ruetz (2006) show that entrapment gear can be effective for capturing round gobies, not all passive gears have performed well. Johnson et al. (2005) found that pot gears (e.g., minnow traps) performed poorly for capturing round gobies. We suspect that gear design partially explains differences in effectiveness among passive gears. For instance, the inside diameter of funnel openings (Shoup et al. 2003; Diana et al. 2006) and the distance from funnel opening to bottom of trap probably affect rates of fish entry and escape from entrapment gear. However, factors other than gear design (potentially related to location or habitat) also are probably important because minnow traps of similar design were effective for capturing round gobies in Lake Michigan (Diana et al. 2006) but not Lake Erie (Johnson et al. 2005). Therefore, use of multiple gears will increase the probability of detecting invasive fishes.

In conclusion, combined use of small-mesh fyke nets and boat electrofishers better represented fish species composition and size structure than either gear alone and increased the detection of rare species. However, use of both gears probably does not eliminate sampling bias. Beamesderfer and Rieman (1988) showed that pooling samples across multiple gears did not eliminate size selectivity (and presumably species selectivity) because each gear did not exactly balance the selectivity of other gears. Comparison of our results with those of other similar studies showed that gear bias is probably dependent on gear design, sampling protocols, and types of habitats sampled. Thus, common generalizations about the types and sizes of fishes captured with entrapment gears and electrofishers (see our initial hypothesis in Introduction) are probably too simplistic and might not be helpful when 
planning and initiating fish assemblage surveys that use slightly different sampling protocols and gear designs.

\section{Acknowledgments}

We thank B. Biddanda, M. Breen, J. Conzelmann, C. Diana, J. Hansen, L. Nemeth, A. Parker, M. Ogdahl, J. Roberts, D. Ruberg, D. VanHaitsma, and E. Vannoy for assistance with field sampling. M. Cooper, A. Steinman, M. Hansen, and four anonymous reviewers provided helpful comments on earlier drafts of this manuscript. This research is a component of the Muskegon Lake Long-Term Monitoring Project, which is supported by the Muskegon Lake Research Endowment Fund managed by the Community Foundation for Muskegon County. A. Steinman was instrumental in establishing the Muskegon Lake Long-Term Monitoring Project.

\section{References}

Basler, M. C., and H. L. Schramm, Jr. 2006. Evaluation of electrofishing and fyke netting for collecting black carp in small ponds. Transactions of the American Fisheries Society 135:277-280.

Beamesderfer, R. C., and B. E. Rieman. 1988. Size selectivity and bias in estimates of population statistics of smallmouth bass, walleye, and northern squawfish in a Columbia River reservoir. North American Journal of Fisheries Management 8:505-510.

Becker, G. C. 1983. Fishes of Wisconsin. University of Wisconsin Press, Madison.

Brazner, J. C., D. K. Tanner, D. A. Jensen, and A. Lemke. 1998. Relative abundance and distribution of ruffe (Gymnocephalus cernuus) in a Lake Superior coastal wetland fish assemblage. Journal of Great Lakes Research 24:293-303.

Breen, M. J., and C. R. Ruetz, III. 2006. Gear bias in fyke netting: evaluating soak time, fish density, and predators. North American Journal of Fisheries Management 26:32-41.

Bunt, C. M., and S. J. Cooke. 2001. Post-spawning movements and habitat use by greater redhorse, Moxostoma valenciennesi. Ecology of Freshwater Fish 10:57-60.

Chick, J. H., S. Coyne, and J. C. Trexler. 1999. Effectiveness of airboat electrofishing for sampling fishes in shallow, vegetated habitats. North American Journal of Fisheries Management 19:957-967.

Clapp, D. F., P. J. Schneeberger, D. J. Jude, G. Madison, and C. Pistis. 2001. Monitoring round goby (Neogobius melanostomus) population expansion in eastern and northern Lake Michigan. Journal of Great Lakes Research 27:335-341.

Corkum, L. D., M. R. Sapota, and K. E. Skora. 2004. The round goby, Neogobius melanostomus, a fish invader on both sides of the Atlantic Ocean. Biological Invasions 6:173-181.

Diana, C. M., J. L. Jonas, R. M. Claramunt, J. D. Fitzsimons, and J. E. Marsden. 2006. A comparison of methods for sampling round goby in rocky littoral areas. North American Journal of Fisheries Management 26:514-522.

Dolan, C. R., and L. E. Miranda. 2003. Immobilization thresholds of electrofishing relative to fish size. Transactions of the American Fisheries Society 132:969-976.

Fago, D. 1998. Comparison of littoral fish assemblages sampled with a mini-fyke net or with a combination of electrofishing and small-mesh seine in Wisconsin Lakes. North American Journal of Fisheries Management 18:731-738.

Holland, R. S., and E. J. Peters. 1992. Differential catch by hoop nets of three mesh sizes in the lower Platte River. North American Journal of Fisheries Management 12:237-243.

Hubbs, C. L., K. F. Lagler, and G. R. Smith. 2004. Fishes of the Great Lakes region, revised edition. University of Michigan Press, Ann Arbor.

Hubert, W. A. 1996. Passive capture techniques. Pages 157192 in B. R. Murphy and D. W. Willis, editors. Fisheries techniques, 2nd edition. American Fisheries Society, Bethesda, Maryland.

Johnson, T. B., M. Allen, L. D. Corkum, and V. A. Lee. 2005. Comparison of methods needed to estimate population size of round gobies (Neogobius melanostomus) in western Lake Erie. Journal of Great Lakes Research 31:78-86.

Jude, D., D. Albert, D. G. Uzarski, and J. Brazner. 2005. Lake Michigan's coastal wetlands: distribution, biological components with emphasis on fish, and threats. Pages 439-477 in T. Edsall and M. Munawar, editors. State of Lake Michigan: ecology, health and management. Aquatic Ecosystem Health and Management Society, Burlington, Ontario.

Knight, J. G., and M. B. Bain. 1996. Sampling fish assemblages in forested floodplain wetlands. Ecology of Freshwater Fish 5:76-85.

Kruskal, J. B., and M. Wish. 1978. Multidimensional scaling. Sage Publications, Sage University paper series on quantitative application in the social sciences, 07-0111, Beverly Hills, California.

Lapointe, N. W. R., L. D. Corkum, and N. E. Mandrak. 2006. A comparison of methods for sampling fish diversity in shallow offshore waters of large rivers. North American Journal of Fisheries Management 26:503-513.

McCune, B., and J. B. Grace. 2002. Analysis of ecological communities. MjM Software Design, Gleneden Beach, Oregon.

Milewski, C. L., and D. W. Willis. 1991. Smallmouth bass size structure and catch rates in five South Dakota lakes as determined from two sampling gears. Prairie Naturalist 23:53-60.

Murphy, B. R., and D. W. Willis, editors. 1996. Fisheries techniques, 2nd edition. American Fisheries Society, Bethesda, Maryland.

Pugh, L. L., and H. L. Schramm, Jr. 1998. Comparison of electrofishing and hoopnetting in lotic habitats of the lower Mississippi River. North American Journal of Fisheries Management 18:649-656.

Reynolds, J. B. 1996. Electrofishing. Pages 221-253 in B. R. Murphy and D. W. Willis, editors. Fisheries techniques, 2nd edition. American Fisheries Society, Bethesda, Maryland. 
Reynolds, J. B., and F. M. Holliman. 2004. Injury of American eels captured by electrofishing and trapnetting. North American Journal of Fisheries Management 24:686-689.

Sammons, S. M., D. A. Isermann, and P. W. Bettoli. 2002. Variation in population characteristics and gear selection between black and white crappies in Tennessee reservoirs: potential effects on management decisions. North American Journal of Fisheries Management 22:863-869.

Sapota, M. R. 2004. The round goby (Neogobius melanosto$m u s$ ) in the Gulf of Gdansk-a species introduction into the Baltic Sea. Hydrobiologia 514:219-224.

Schultz, R. D., and D. E. Haines. 2005. Comparison of seasonal bluegill catch rates and size distributions obtained with trap nets and electrofishing in a large, heated impoundment. North American Journal of Fisheries Management 25:220-224.

Shoup, D. E., R. E. Carlson, R. T. Heath, and M. W. Kershner. 2003. Comparison of the species composition, catch rate, and length distribution of the catch from trap nets with three different mesh and throat size combinations. North American Journal of Fisheries Management 23:462-469.

Uzarski, D. G., T. M. Burton, M. J. Cooper, J. W. Ingram, and S. T. A. Timmermans. 2005. Fish habitat use within and across wetland classes in coastal wetlands of the five Great Lakes: development of a fish based index of biotic integrity. Journal of Great Lakes Research 31(Supplement 1):171-187.

Vaux, P. D., T. R. Whittier, G. DeCesare, and J. P. Kurtenbach. 2000. Evaluation of a backpack electrofishing unit for multiple lake surveys of fish assemblage structure. North American Journal of Fisheries Management 20:168-179.

Weaver, M. J., J. J. Magnuson, and M. K. Clayton. 1993. Analyses for differentiating littoral fish assemblages with catch data from multiple sampling gears. Transactions of the North American Fisheries Society 122:1111-1119.

Zimmerman, G. M., H. Goetz, and P. W. Mielke, Jr. 1985. Use of an improved statistical method for group comparisons to study effects of prairie fire. Ecology 66:606611. 